\title{
Making Changes in the Course of a European PROJECT AND INFRINGEMENTS OF COMMUNITY LAW
}

\author{
WEADYSEAW SZMYT*
}

\section{INTRODUCTION}

As far as the utilization of European structural funds in Polish practice by various business entities is concerned, the issue of departures from the assumptions established in the documentation of the project by the authors of the so-called European projects appears frequently. The projects are economically indivisible series of works fulfilling a precise technical function with clearly delineated aims. A project may stand alone or be composed of several sub-projects and project promoters can be all and any of the public sector institutions as well as private and non-governmental organizations with legal personality in non-governmental and the beneficiary's organizations, national or regional authorities, research and academic institutions, civil society organizations and organizations created by a public-private partnership ${ }^{1}$. Documentation of the project in the process of project implementation is generally treated as conditio sine qua non of proper project execution and both the authors and the project contractors are convinced that deviations from the assumptions specified in the documentation are basically unacceptable. Executive experience, however, as is often the case in everyday life, forces the contractors to introduce certain changes during project implementation, despite the fact that according to documentation, specifically designated and described materials should be used, for example. However, one must be aware of the general principle that every project must be implemented in accordance with the agreement signed by the beneficiary of the grant.

DOI: $10.1515 /$ wrlae-2015-0004

*PhD, Assistant Professor, University of Wrocław, Institute of Economic Sciences, Department of International Economic Relations.

${ }^{1}$ Jarosław Kundera and Władysław Szmyt, Leksykon polityki regionalnej Unii Europejskiej (Wolters Kluwer 2008) 88. 


\section{Making Changes to the Project as a Presumption of IRREGULARITY}

Experience in the utilization of European Union funds in Poland ${ }^{2}$ shows that numerous doubts and dilemmas appear regarding beneficiaries who use components which may be treated as counterparts or substitutes of the components specified in tender documentation in the project executed and implemented with the help of the European Union funds (public funds). This raises the question of whether such a practice is a breach of the provisions of Community law, and in particular provisions concerning damage to the interest of the European Union budget. An issue of a similar nature appears in beneficiary-contractor relations as well, unless the beneficiary is also the project contractor. In situations where the implementation of work is considerably complex, and during the execution of European projects in general (specifically including so-called major projects of substantial value that need to be executed by specialized companies), all alterations that appear during project execution may lead to misunderstandings between the project contractor and beneficiary (the beneficiary is a customer in such a case and he establishes requirements and specifies them in project documentation) $)^{3}$. Moreover, beneficiaries may believe that departures from the assumptions specified in the documentation may result in monetary sanctions ordered by relevant authorities overseeing the proper spending of European Union resources (such as e.g. discontinuing the next allocation or even an order to return irregular expenditure) and each incident of this type shall be treated as an irregularity without any exceptions. Thus, the question arises as to which breaches concerning the execution of European Union projects are treated as unacceptable under Community law.

\section{IRREGULARITIES OR DAMAGE TO THE COMMUNITY BUDGET}

Such breaches are generally defined as irregularities. The aforementioned problem raises the question of whether the abovementioned infringements, on the side of both beneficiary and project executor, constitute an irregularity. Pursuant to Article 2 (7) of Council Regulation (EC) No. 1083/2006 of 11 July 2006 laying down general

\footnotetext{
2 Polish experience in the use of funds under the regional policy concerns mainly Structural Funds (2004-2013, part-time financial perspective 2000-2006 and a full financial perspective 2007-2013). Nevertheless, it is worth noting that Poland benefited from structural help before accession to the EU, using specific pre-accession funds, therefore the opinion of a high degree of experience of Polish beneficiaries of EU funds is correct.
}

\footnotetext{
${ }^{3}$ It is frequently stressed in the literature on project management that defining customer requirements is one of the key tasks at the planning and monitoring stages. This means identifying the customer's expectations and every contractor should "sense" the expectations of the party ordering project execution. Amendments of requirements during project execution are one of the issues relating to specification of the customer's requirements. See J Davidson Frame, The financial management of the European project (WIG Press 2003) 123-130.
} 
provisions on the European Regional Development Fund, the European Social Fund and the Cohesion Fund, an 'irregularity' is any infringement of a provision of Community law resulting from an act or omission by an economic operator which has, or would have, the effect of prejudicing the general budget of the European Union by charging an unjustified item of expenditure to the general budget ${ }^{4}$.

Referring to the general rules of civil law, the damage to the EU budget is determined in two ways, as follows:

- Real damage - Community funds that have been improperly paid to the beneficiary;

- Potential damage - Community funds which could have been improperly paid to the beneficiary, had the irregularity not been identified.

The concept of fraud should also be indicated, which refers to any intentional act or omission affecting the financial interests of the European Communities in respect of expenditure, such as:

- The use or presentation of false, incorrect or incomplete statements or documents to misappropriate or wrongfully keep funds from the general budget of the EC, or budgets managed by the Communities or on their behalf;

- The non-disclosure of information, despite the existence of a specific obligation in this respect, for the same purpose;

- The misuse of such funds for purposes other than those for which they were originally granted.

Guidance on corrections of unjustified expenditures incurred as part of Operational Projects (e.g. Operational Project Infrastructure and Environment, chapter 3) stipulates that irregularity may be claimed on the following three grounds:

1. an infringement of law

2. such infringement must result from an act or omission by an economic operator

3. the act or omission must have, or would have, the effect of prejudicing the general budget of the European Union by charging an unjustified item of expenditure to the general budget ${ }^{5}$.

Guidance from the Ministry of Regional Development on the action to be taken in the event of detecting irregularities in the utilization of structural funds and Cohesion Fund extend the term of infringement of law

\footnotetext{
${ }^{4}$ As part of Polish financial law, there are also regulations referring to the issue of violations of the principles that determine the procedures for the financing of projects and programmes in part with funds from the EU budget. These particularly include the provisions of the Responsibility for Public Finance Discipline Act of 17 December 2004 (Journal of Laws 2005, no 14, item 114 as amended).

See Wiesława Miemiec, 'Konsekwencje nieprawidłowego wykorzystania bezzwrotnych środków unijnych w ustawie o odpowiedzialności za naruszenie dyscypliny finansów publicznych' in Wiesława Miemiec (ed), Europejskie bezzwrotne źródła finansowania polityki regionalnej w Polsce. Aspekty prawno - finansowe (UNIMEX 2012) 273 - 289.

5 Narodowe Strategiczne Ramy odniesienia 2007-2013.Wytyczne $w$ zakresie sposobu korygowania wydatków nieprawidłowo poniesionych $w$ ramach Programu Operacyjnego Infrastruktura i Środowisko 2007-2013, Chapter 3, point 3.
} 
on to state law on the utilization of structural funds, even when state law is more restrictive than Community law ${ }^{6}$.

In any case where financial loss is not incurred (the potential or actual effect of prejudicing the budget), a given infringement cannot be classified as an irregularity. Thus, there are no grounds to initiate the procedure recognizing any expenditure as irregular (e.g. the occurrence of faults, defects, or procedural infringements which do not result in financial loss).

Provisions of Community law account for several types of irregularities: irregularities concerning account settlement, failure to maintain correct accounting documentation, incorrectly completed application forms for financial aid, inadequate or incorrectly completed documentation (detecting irregularities after accepting application for financial aid), ineligible costs, fraud, breach of terms and conditions of the agreement or European Council decision, irregularities in execution of the project $^{7}$.

The analysis of applications of the provisions on irregularities and action taken upon detection of irregularities by controlling units and audit authorities $^{8}$ (such as the Managing Authority, Intermediate Body, Certifying Authority or other) shows that the last two kinds of irregularities should primarily be taken into account. These kinds of irregularities may apply in the event that the business entity - the project contractor - introduces changes to some of the project components. The following irregularities are seen as a breach of the terms and conditions of the agreement:

\footnotetext{
${ }^{6}$ In Polish law, there is no single normative act regulating the issues of irregularities in a comprehensive manner. See Jarosław Odachowski, 'Pojęcie nieprawidłowości wykorzystania przyznanych środków w prawie UE' in Miemiec (n 4) 221-240.

${ }^{7}$ Council Act of 26 July 1995 setting out the Convention on the protection of the financial interests of the European Communities [1995] OJ C 316; Wytyczne Ministra Rozwoju Regionalnego $\mathrm{w}$ zakresie sposobu postępowania $\mathrm{w}$ razie wykrycia nieprawidłowości $\mathrm{w}$ wykorzystaniu funduszy strukturalnych i Funduszu Spójności w okresie programowania 2007-2013 z dnia 8 lutego 2011 r.; Council Regulation (EC) 1083/2006 of 8 December 2006 laying down detailed rules for the implementation of Council Regulation (EC) 1083/2006 laying down general provisions on the European Regional Development Fund, the European Social Fund and the Cohesion Fund and of Regulation (EC) 1080/2006 of the European Parliament and of the Council on the European Regional Development Fund; Najwyższa Izba Kontroli, 'Kontrola w zakresie funduszy strukturalnych i funduszu spójności - podstawowe zasady działań kontrolnych, wykrywanie nieprawidłowości i ich konsekwencje', (2013) 2 (331) Kontrola Państwowa, [www.nik.gov.pl]; Commission Regulation (EC) 1828/2006 of 8 December 2006 laying down detailed rules for the implementation of Council Regulation (EC) No. 1083/2006 laying down general provisions on the European Regional Development Fund, the European Social Fund and the Cohesion Fund and of Regulation (EC) 1080/2006 of the European Parliament and of the Council on the European Regional Development Fund [2006] OJ L 371/1.

${ }^{8}$ Project audit is obligatory and it is carried out according to Council Regulation (EC) 1083/2006 of 11 July 2006 laying down general provisions on the European Regional Development Fund, the European Social Fund and the Cohesion Fund. Audit terms and rules are specified in National Strategic Reference Framework: Warsaw 2007 (Guidance on the control process for intermediate bodies and implementing institutions). Ad-hoc inspections may be ordered on request, upon a complaint, or in the event there are reasonable grounds to suspect an irregularity, or where it is a consequence of a different inspection which reported irregularities. See Marek Dylewski, Beata Filipiak, Adrian Guranowski and Joanna Hołub-Iwan, Zarządzanie finansami projektu europejskiego (C.H. Beck 2009) 238 .
} 
1. A failure to respect deadlines

2. Performing an operation which is not specified in the project

3. A failure to respect a fixed or declared price

4. The absence of a declaration or late return of such

5. Irregular or unpermitted financing (e.g. combining aid from different sources)

6. The absence of evidence required

7. A refusal to submit to an audit

8. A refusal to make a payment

9. The absence or incompatibility of a contract

10. Multiple requests for the same subject

11. A failure to respect other regulations/contract conditions

12. An infringement of the rules governing public procurement The following irregularities are seen as irregularities concerning carrying out the action (executing the project):

1. An action not carried out

2. An action not completed

3. An action not carried out in accordance with rules (e.g. provisions of the construction law)

4. Unjustified expenditure

5. Expenditure not related to the period in which action was carried out (e.g. expenditure not incurred in the period in which action was carried out)

6. Expenditure not legitimate

7. Overfinancing (qualified expenditure is higher than the market price of goods or services)

8. Insufficient contribution from the Member State, infringement of the co-financing rules

9. Revenue not declared

10. Fraud

The most common irregularities that appear in Polish practice of the utilization of structural funds:

1. Non-compliance with public procurement guidance;

2. False or falsified documents;

3. Ineligible costs;

4. A failure to execute the project in the scope established;

5. The absence of accounts;

6. A failure to respect a co-financing contract;

7. Incomplete or incorrect request for aid.

In view of the catalogue of irregularities outlined above ${ }^{9}$, a given project should be "checked" each time against the above mentioned actions

\footnotetext{
9 The issue of irregularities, fraud, errors, etc. is much wider, but this goes beyond the subject of the article. Another issue, though, of course, linked to the issue of European projects is in the area of program management and operational control over its execution, where the prevention and correction of irregularities is a fundamental task of managing and establishing the beneficiary of the entire system of control by the state. See (n 7) and Tomasz Kierzkowski (ed), Agnieszka Jankowska and Robert Knopik, Fundusze strukturalne oraz Fundusz Spójności. Komentarz do rozporządzenia Rady Unii Europejskiej nr 1083/2006 z dnia 11 lipca 2006 r. ustanawiajacego przepisy ogólne dotyczace
} 
and omissions that account for irregularities. Thus, in each case it needs to be examined whether the actions of the beneficiary of the funds consisting of introducing amendments to the project by using counterparts of the components declared in the project (as long as there is no infringement of key assumptions of the project, such as project objectives ${ }^{10}$, output indicators, result indicators) do not unequivocally exhaust the abovespecified breaches and irregularities.

\section{CONCLUSIONS}

The aforementioned types of breaches of the rules governing utilization of the European Union funds set up to provide structural assistance indicate that the action of using a component different than the one specified in the documentation by project contractor who is acting on behalf of the beneficiary, or by the beneficiary who is project executor of the project co-financed by the European Union structural funds and Cohesion Fund, does not give grounds to initiate legal proceedings in order to establish the presence of irregularity.

Experiences and observations of the practice of the wording of contracts and application of clauses relevant to subject matter discussed herein shows that both parties to the said agreements (the Ordering Party and the Contractor) tend to find compromise solutions that satisfy both parties, but do not breach the general provisions of Community law on the subject matter. Specific contractual provisions hereof can be found in the documentation of the project implemented by one of the community companies from Wielkopolskie province. In the material contract terms there is a clause allowing the contractor to use counterparts that meet relevant technical and quality regulations and whose performance characteristics are not worse than those specified in the documentation prepared by the Ordering Party. The Contractor that invokes a counterpart solution specified by the Ordering Party shall prove that the counterparts he used (deliveries, services, construction works) meet the basic requirements specified by the Ordering Party. The drafter of the specification explains that products, articles and appliances having different names than those specified in the material contract terms are acceptable, as long as their parameters are not worse than the performance characteristics of the items specified in the documentation, or preferably have better performance characteristics that meet the relevant functional, technical and quality regulations specified in the documentation, and have performance characteristics meeting the functional requirements of the items specified in the documentation of the Ordering Party ${ }^{11}$.

Europejskiego Funduszu Rozwoju Regionalnego, Europejskiego Funduszu Społecznego oraz Funduszu Spójności (C.H. Beck 2009) 554-577.

10 The basis of all project objectives are: excellence of result, costs of project implementation and time of project implementation. Excellence concerns meeting quality requirements as to project results.

${ }^{11}$ Specification of material contract terms for procedures for awarding a contract in open procedure for implementation of the project 'Kompleksowe zagospodarowanie ścieków zlewni Obry-Gmina Nowy Tomyśl'( 'Complex management of waste treatment in Obra subbasin-Nowy Tomyśl Commune’). Project implemented by Municipal Water and Sewerage 
Certain analogies from the Community law, although not directly related to the cases analysed herein, provide good examples of solutions and resolutions adopted in similar subject matter. This is the case with provisions regarding using counterparts in active medical devices ${ }^{12}$, where the authors of the provisions (here, the European Commission) specify certain aspects relating to risk analysis and risk management for justification of the use of animal tissues or derivatives: "the manufacturer must justify, on the basis of the overall risk analysis and risk management strategy for a specific medical device, the decision to use animal tissues or derivatives, referred to in Article 1, (specifying animal species, tissues and sourcing) taking into account the clinical benefit, potential residual risk and suitable alternatives (such as lower risk tissues or synthetic alternatives)."

Similarly, provisions governing the usage of substitutes by manufacturers and service providers do not rule out their usage, as long as the consumer gives his consent. However, these provisions apply mainly in cases of repairs, but neither the legislator nor court verdicts rule out the possibility of such performance of the agreement or restoration to a previous condition. According to case law, a repair means restoring to its previous condition. This concerns not only the technical condition and goods' fitness for use, but also its component parts, durability and aesthetics ${ }^{13}$. The choice of the kind of repair belongs to the customer and it cannot be imposed on him. Hence, if the buyer requests original parts to be used for repair, the seller must not use counterparts. The buyer may voluntarily give his consent to the usage of counterparts. Nonetheless, there is no doubt that the counterparts should be of similar quality, as otherwise the requirement of goods' fitness for use shall not be fulfilled.

The Office for Competition and Consumer Protection holds a similar opinion. In answer to a question regarding whether an entrepreneur is obliged to use original parts to remedy nonconformity of goods with the contract or whether he is allowed use substitutes, the Office for Competition and Consumer Protection replies: "using counterparts of visible components is fully acceptable, as such a situation is covered by the provisions of the socalled 'repair clause.' According to Article 1061 of the Act of 30 July 2000 on industrial property law (Journal of Laws 2003, no 119, item 1117 as amended), when repairing an item with a view to restoring its former condition, usage of parts coming from entities not holding rights to registration of designs is acceptable." This provision is most frequently applied in car repairs and it allows usage of counterparts in such cases. There is no obligation, however, to use counterparts for repair of faulty parts or to use parts provided by the manufacturer, although such practices are convenient for insurance companies that may then pay smaller claims.

Company in Nowy Tomyśl Sp. zo.o. (Przedsiębiorstwo Wodociągów i Kanalizacji w Nowym Tomyślu) within operational programme 'Infrastructure and Environment'.

12 Commission Regulation (EU) 722/2012 of 8 August 2012 concerning particular requirements as regards the requirements laid down in Council Directives 90/385/EEC and 93/42/EEC with respect to active implantable medical devices and medical devices manufactured utilising tissues of animal origin [2012] OJ L 212/3.

${ }^{13}$ According to the ruling of Court of Appeal in Łódź of 10 November 1992 (I ACr 410/92). 
According to Article 8 (4) of the Act of 27 July 2002 on specific terms and conditions of consumer sale (Journal of Laws 2002, no 141, item 1176 as amended), a buyer may give his consent to the repair with the use of a counterpart and he is then entitled to an appropriate price reduction, if installation of the original part is unfeasible or it entails excessive costs. ${ }^{14}$

As the case discussed above shows - although they are not directly related to the analysed issue of departures from the original documentation of European projects and using substitutes in them -using such components is permitted by both state and Community law and such a practice does not unequivocally influence the situation of the stakeholders of the projects, especially the beneficiaries.

14 http://www.uokik.gov.pl/faq_sprzedaz_konsumencka.php, accessed 15 February 2013. 